УДК 37.04

\title{
ШКОЛЬНАЯ МЕДИАЦИЯ В РОССИИ: ПРОБЛЕМЫ РАЗВИТИЯ
}

\author{
Вечерина Ольга Павловна \\ кандидат исторических наук, \\ доцент кафедры медиации в социальной сфере \\ Московский государственный \\ психолого-педагогический университет
}

\begin{abstract}
Аннотация: Предмет исследования - проблемы развития всероссийской сети служб школьной медиации и школьных служб примирения. Автором рассмотрены причины и основные этапы их создания, особенности работы. На основе анализа нормативно-правовой базы и исследовательской литературы выявлены основные проблемы развития, связанные как с региональной спецификой, так и с отсутствием реальных механизмов по повышению уровня эффективности их работы.

Ключевые слова: медиация, школьная медиация, восстановительное правосудие, медиативный подход, службы школьной медиации, школьные службы примирения
\end{abstract}

\section{SCHOOL MEDIATION IN RUSSIA: DEVELOPMENT PROBLEMS}

\section{Vecherina Olga Pavlovna}

\begin{abstract}
The subject of this research is the problems of developing the allRussian network of school mediation services and school reconciliation services. The author considers the reasons and the main stages of their creation, the features of their work. Based on the regulatory framework and research literature analysis, the main development problems associated with regional specifics and the lack of actual mechanisms to increase their work efficiency have been identified.

Key words: mediation, school mediation, restorative justice, mediation approach, school mediation services, school reconciliation services

По состоянию на лето 2021 г. метод школьной медиации применяется во всех регионах Российской Федерации, с ним работают десятки тысяч человек [1]. В целом можно сказать, что первая стадия эксперимента и апробации уже
\end{abstract}


позади. Метод в целом показал свою эффективность, однако его успешность тесно связана с проблемами качественной подготовки кадров, с чем пока в стране существуют серьезные проблемы.

Накопленный на сегодня опыт развития школьной медиации позволяет говорить, что эта технология - один из лучших инструментов по созданию безопасной среды в пространстве обучающей организации. Начало его развитию было положено в конце 1970-х гг. в США, когда американские школы захлестнула волна насилия и буллинга, на базе соединения подходов медиации и восстановительного правосудия [2]. В настоящее время службы школьной медиации работают во многих странах мира [3, с. 18-30].

В России развитие сети школьных служб примирения и служб школьной медиации, первоначально продвигаемое силами энтузиастов в рамках различных экспериментов и пилотных проектов, в своем развитии прошло уже несколько этапов: теоретической разработки метода, создания нормативноправовой базы для его внедрения, пилотных проектов и отработки методических рекомендаций по внедрению, имплементации метода в образовательную среду российской школы и массовой подготовки специалистов, способных грамотно и эффективно работать с детьми с помощью этого метода (подробнее см. [4]).

В России метод «Школьная медиация» развивался и адаптировался к российским условиям в рамках общих направлений и этапов развития российского института медиации (подробнее см. [5, с. 47-63]). Деятельное участие в этом процессе, разрабатывая как теоретические, так и нормативноправовые документы на основе содействующей модели медиации (этот метод во многом предопределил идеологию системы СШМ), принимали сотрудники Научно-методического центра медиации и права и Федерального института медиации, возглавляемых Ц. А. Шамликашвили [6] [7, с. 26-33].

Метод «Восстановительная медиация» разработан Р. Р. Максудовым и основан на идеях восстановительного правосудия [8]. Свое современное развитие восстановительное правосудие получило в 1970-х гг. как идея альтернативы уголовным наказаниям, основанная на осознании преступником вреда, нанесенного им жертве, и работе специалистов с его психологическими переживаниями, возникающими по этому поводу - стыдом, сочувствием и т.п., что должно привести к возмещения ущерба и новой интеграции правонарушителя в жизнь общества. [9].

Переход от пилотных проектов требовал подготовки и создания новой 
нормативно-правовой базы, позволяющей интегрировать эти методы в школу и начать планомерную подготовку соответствующих специалистов.

Фундаментом создания новой системы предупреждения и работы с конфликтами стали утвержденная Указом Президента Российской Федерации от 1 июня 2012 г. «Национальная стратегии действий в интересах детей на 2012-2017 годы» и «План первоочередных мероприятий до 2014 года по реализации важнейших положений Национальной стратегии действий в интересах детей на 2012-2017 годы», утвержденный 15 октября 2012 г. Председателем Правительства Российской Федерации (Распоряжение № 1916-p). В соответствии с п. 64 этого Плана, Минобрнауки России направило методические рекомендации по организации служб школьной медиации в образовательных организациях (Письмо от 18 ноября 2013 г. № ВК-844/07), в котором были в том числе даны определения метода «школьная медиация» и медиативного подхода [10].

Важным этапом в создании всероссийской сети служб школьной медиации стало утверждение метода медиации как основного инструмента реализации «Концепции развития до 2017 года сети служб медиации в целях реализации восстановительного правосудия в отношении детей, в том числе совершивших общественно опасные деяния, но не достигших возраста, с которого наступает уголовная ответственность в Российской Федерации» [11].

Во исполнение поручения Президента по итогам заседания президиума Госсовета о государственной политике в сфере семьи, материнства и детства 4 марта 2014 г., поручением Заместителя Председателя Правительства РФ (№ ОГ-П4-3106 от 08.05.2015) был утвержден «Межведомственный план комплексных мероприятий» по реализации вышеуказанной концепции.

1 сентября 2018 г. Распоряжением № 1837-р Правительства Российской Федерации были утверждены изменения «О продлении до 2020 года срока реализации Концепции развития до 2017 года сети служб медиации в целях реализации восстановительного правосудия в отношении детей, в том числе совершивших общественно опасные деяния, но не достигших возраста, с которого наступает уголовная ответственность в Российской Федерации, утвержденной распоряжением Правительства Российской Федерации от 30 июля 2014 г. № 1430» [13].

25 сентября 2019 г. Правительственной комиссией по делам несовершеннолетних и защите их прав утвержден новый «Межведомственный план комплексных мероприятий по реализации Концепции...», до 2025 г. [12]. 
Эти нормативные документы стали основой для создания всероссийской системы служб школьной медиации. Основные положения по ее созданию были разработаны ФГБУ «Федеральный институт медиации», созданном Министерством образования и науки в 2013 г. для реализации этих задач. Сотрудниками были разработаны «Методические рекомендации по созданию и развитию служб школьной медиации в образовательных организациях» [14]. Институт также подготовил две пилотных группы школьных медиаторов, отработав в этих проектах технологию массовой подготовки специалистов.

В то же время службы восстановительной медиации в форме школьных служб примирения, которые начали развиваться с начала 2000-х гг., до настоящего времени они существуют и развиваются в России на основе «Методических рекомендаций по созданию и развитию служб примирения в образовательных организациях» [15], созданных специалистами Всероссийской ассоциации восстановительной медиации и разосланных Министерством образования и науки Российской Федерации вместе с «Методическими рекомендациями...» ФГБУ «ФИМ» в качестве возможной альтернативы (Письмо №7-4317 от 18.12.2015 «О направлении методических рекомендаций»).

И то, и другое направление превенции и разрешения конфликтов в образовательной среде до последнего времени развивались параллельно и независимо друг от друга, что, безусловно, являлось сдерживающим фактором для развития всей системы в целом, во многом обусловившим трудности этого первоначального этапа имплементации этого метода.

Несмотря на трудности, связанные как с параллелизмом внедряемых методик (попытка их объединить была предпринята только в 2020 г., в новых Методических рекомендациях Министерства просвещения РФ [16]), так и с нехваткой разъясняющих методических материалов, надлежащего финансового и кадрового обеспечения, в настоящее время службы школьной медиации/школьные службы примирения созданы практически во всех регионах страны. Первые итоги были подведены на Всероссийском совещании школьных служб примирения и медиации, проведенном Министерством просвещения РФ 24 сентября 2020 г. Был обобщен опыт реализации основных положений Концепции, параллельного развития СШМ и ШСП, намечены новые перспективы развития и более полного раскрытия потенциала медиации. Всего в работе совещания приняли участие 446 человек из 85 регионов страны, 
по итогам была принята резолюция и выпушен сборник тезисов докладов участников [17].

Ряд положений резолюции прямо направлен на решение проблемы подготовки кадров, которая сегодня представляется главной для успешного развития созданного этого нового социального института, в котором сегодня уже работают более 25000 служб и около 80000 человек [17, с. 9]. Признано целесообразным разработать единую систему подготовки кадров, начиная с бакалавриата, по укрупненным группам специальностей и направлений подготовки «Образование и педагогические науки» в соответствии с профстандартом «Специалист в области медиации (медиатор)». Намечена также разработка типовой программы ДПО (подробнее о проблемах подготовки медиаторов в России см. [18, с.1-13]).

Среди основных проблем развития, сформулированных и озвученных участниками совещания, выделим следующие:

1) Недостаточное владение специалистов практикой применения медиативных технологий;

2) Отсутствие разработанной теории и практических алгоритмов определения медиабельности конфликтов (особенно в случаях многоуровневых конфликтов);

3) Трудности выбора базовой модели медиации или примирения для внедрения;

4) Быстрый рост социального неравенства в обществе и, как следствие, конфликтогенности образовательной среды;

5) Культурная травма и выраженная социальная фрустрация значительных групп населения, обусловленная сломом или обесцениванием ценностей советского периода;

6) Отсутствие внятной и доступной информации об успешных практиках школьной медиации (частично эту проблему попыталось решить Совещание и выпущенный по его итогам Сборник);

7) Проблемы функционала и статуса территориальных служб примирения как части гражданского движения восстановительных практик;

8) Проблемы дистанционного развития.

В то же время доклады участников и опубликованные в сборнике многочисленные свидетельства об успешном развитии медиации в целом ряде регионов позволяют обоснованно утверждать, что институт школьной 
медиации не только состоялся и получил признание общества, но и имеет большой потенциал для развития.

\section{Список литературы}

1. Аналитический доклад «Мониторинг деятельности служб медиации в субъектах Российской Федерации» [Электронный ресурс] // Официальный сайт Федерального центра зашиты прав и интересов детей. - М., 2021. https://fcprc.ru/wp-content/uploads/2021/06/Monitoring-2020-21.pdf_ (дата обращения: 10.08.2021).

2. Murray B. A. Examining School Based Mediation: A Literature Review / A Research Paper Submitted in Partial Fulfillment of the Requirements for the Master of Science Degree with a Major in Guidance and Counseling. - The Graduate College University of Wisconsin, 2003. -39 p.

3. Коновалов А. Ю. Медиация в системе образования : обзор опыта разных стран // Психологическая наука и образование. - 2014. - № 3. - С. 18 30 .

4. Коновалов А. Ю. Школьная служба примирения и восстановительная культура взаимоотношений: практическое руководство / под ред. Л.М. Карнозовой. Изд. 2-е, дораб. - М.: Судебно-правовая реформа, 2014. - 306 с.

5. Вечерина О. П., Путалова И. Б. Структура российского института медиации: настоящее, прошлое, будущее // Юридические исследования. - 2020. - № 9. - C. 47-63. DOI: 10.25136/2409-7136.2020.9.34287

6. Шамликашвили Ц. А. Школьная медиация как действенный инструмент в защите прав детей [Электронный ресурс] // ИА «ГаранТ». 30.08.13. - http://www.garant.ru/ia/opinion/author/shamlikashvili/509291/ (дата обращения: 10.08.2021).

7. Шамликашвили Ц. А., Хазанова М. А. Метод «школьная медиация» как способ создания безопасного пространства и его психологические механизмы // Психологическая наука и образование. - 2014. - № 2. - С. 26-33.

8. Максудов Р. Р. Базовые элементы концепции восстановительной медиации // Психология и право. - 2012. - № 4. - С. 1-9.

9. Кульман А., Кури Х. Восстановительное правосудие как альтернатива уголовным наказаниям - уроки истории // Актуальные проблемы экономики и права. 2016. Т. 10. № 4. С. 126-149.

10. Письмо Минобрнауки России от 18.11.2013 № $\mathrm{BK}-844 / 07$ «О направлении методических рекомендаций по организации служб школьной 142 
медиации» (вместе с «Рекомендациями по организации служб школьной медиации в образовательных организациях», утв. Минобрнауки России 18.11.2013 № ВK-54/07Bн).

11. Концепция развития до 2017 года служб медиации в целях реализации восстановительного правосудия в отношении детей, в том числе совершивших общественно опасные деяния, но не достигших возраста, с которого наступает уголовная ответственность в Российской Федерации. Распоряжение Правительства Российской Федерации от 30 июля 2014 года № 1430-р [Электронный ресурс] // Собрание законодательства Российской Федерации. 2014. - № 32. - ст. 4557. - http://docs.cntd.ru/document/420211300 (дата обращения: 10.08.2021).

12. Межведомственный план комплексных мероприятий по реализации Концепции развития сети служб медиации в целях реализации восстановительного правосудия в отношении детей, в том числе совершивших общественно опасные деяния, но не достигших возраста, с которого наступает уголовная ответственность в Российской Федерации, до 2025 года. Утвержден Правительственной комиссией по делам несовершеннолетних и защите их прав 25 сентября 2019 г. [Электронный pecypc]. - http://fedim.ru/services-ofmediation/mezhvedomstvennyj-plan-kompleksnyh-meropriyatij-po-realizatsiikontseptsii/ (дата обращения: 10.11.2020).

13. О продлении до 2020 года срока реализации Концепции развития до 2017 года сети служб медиации в целях реализации восстановительного правосудия в отношении детей, в том числе совершивших общественно опасные деяния, но не достигших возраста, с которого наступает уголовная ответственность в Российской Федерации, утвержденной распоряжением Правительства Российской Федерации от 30 июля 2014 г. № 1430-р. Правительство Российской Федерации. Распоряжение от 1 сентября 2018 года № 1837-p. [Электронный pecypc]. - http://docs.cntd.ru/document/551031865 (дата обращения: 10.08.2021).

14. Методические рекомендации по созданию и развитию служб школьной медиации в образовательных организациях / ФГБУ «ФИМ» (направлены письмом Минобрнауки России от 18.12.2015 № 07-4317). [Электронный ресурс]. - http://www.consultant.ru/document/cons_doc_LAW_ 256446/ (дата обращения: 10.08.2021).

15. Методические рекомендации по созданию и развитию школьных служб примирения / Всероссийская ассоциация восстановительной медиации 
(направлены письмом Минобрнауки России от 18.12.2015 № 07-4317). [Электронный pecypc]. - http://www.consultant.ru/document/cons_doc_LAW_ 256446/ (дата обращения: 10.08.2021).

16. Методические рекомендации по развитию сети служб медиации (примирения) в образовательных организациях и в организациях для детейсирот и детей, оставшихся без попечения родителей (направлены письмом Министерства просвещения России от 28.04.2020 № ДГ-375/07) [Электронный pecypc]. - http://www.consultant.ru/document/cons_doc_LAW_352492/cec075f0903 ffc16f6081a06d44423a528e421a9/ (дата обращения: 10.08.2021).

17. Всероссийское совещание школьных служб примирения и медиации : Сборник материалов / под ред. Н. В. Горлийчука. - М.: ФГБУ «Центр защиты прав и интересов детей», 2020. -433 с.

18. Вечерина О.П., Путалова И.Б. Проблемы профессиональной подготовки медиаторов в России // Современное образование. 2021. - № 1. C. 1-13. - DOI: 10.25136/2409-8736.2021.1.34746.

(c) О.П. Вечерина, 2021 